\title{
Cortijo de San Isidro (La Rebanadilla) in the bay of Málaga, Spain: Observations on small finds from the burials. The seal-amulets
}

\section{El Cortijo de San Isidro (La Rebanadilla), Bahía de Málaga, España: Observaciones sobre pequeños hallazgos en enterramientos. Los sellos-amuletos}

\author{
Vanessa Boschloos*, Mar Juzgado**, Vicente Marcos Sánchez***, Lorenzo Galindo****. \\ Recibido: 02-03-2018 \\ Aceptado: 11-09-2018
}

\begin{abstract}
Resumen
Durante este trabajo se aborda el estudio de los tres escarabeos y un sello o escaraboide localizados asociados a las tumbas más antiguas de la necrópolis fenicia arcaica de Cortijo de San Isidro (Málaga). La cronología de finales del s. IX a.C. de las tumbas en las que se localizan hace que estemos ante los primeros ejemplos de estos materiales en la Península Ibérica, por el momento. Desde este trabajo se aborda su clasificación tipológica y su comparación con otros ejemplares localizados en otras áreas del Mediterráneo, con la finalidad de determinar su procedencia y su cronología comparativa.
\end{abstract}

Palabras clave: Andalucía, arqueología fenicia, aegyptiaca, escarabeos, iconografía

\begin{abstract}
This paper presents the study of three scarabs and a cowroid found associated with the oldest tombs of the Archaic Phoenician necropolis of Cortijo de San Isidro (Málaga, Spain). The late $9^{\text {th }}$ century BC date of the burials in which they surfaced suggests that the seal-amulets are among the earliest examples of this type of object in the Iberian Peninsula. In a discussion on typological classification and on the comparison with similar finds from other areas of the Mediterranean, we aim to determine their origin and comparative chronology.
\end{abstract}

Key words: Andalusia, Phoenician archaeology, aegyptiaca, scarab seals, iconography

\section{INTRODUCTION}

Our knowledge of Phoenician funerary practices is for a large part based on the results of excavation campaigns undertaken in the Phoenician Levant, whereas archaeological excavations at sites in the Central and West Mediterranean with clear Phoenician presence, allow to determine to what degree practices, burial gifts, chronological developments, etc. concord or defer in different regions. Cortijo de San Isidro in Málaga Airport is one of the sites shedding light on funerary practices at a Phoenician necropolis in southern Spain. It is located $3 \mathrm{~km}$ inland on the river Guadalhorce and associated with the settlement of La
Rebanadilla, at about $400 \mathrm{~m}$ distance to the northeast (Fig. 1). The earliest phases of both sites are radiocarbon dated to the (late) $9^{\text {th }}$ century $\mathrm{BC}$, when the Phoenician colonisation of the Málaga region is said to have begun (Aubet, 2001: 307-308, 381, appendix III; Arancibia et al., 2011; Pappa, 2013: 6-8). Together with its necropolis at Cortijo de San Isidro (Navarro et al., 2016), La Rebanadilla (Sánchez et al., 2011; Sánchez et al., 2012) is thus part of the series of early Phoenician settlements in the bay of Málaga. It is also the site of one of the oldest documented Phoenician sanctuaries in the Iberian Peninsula (Pappa, 2013: 6668; Sánchez et al., in press).
* Ghent University, Department of Archaeology, vanessa.boschloos@ugent.be, No Orcid: 0000-0003-4654-3134

** UNED (Centro asociado de Cuenca) marjuzgado@ gmail.com; $\mathrm{N}^{\circ}$ Orcid: 0000-0003-4148-6687
*** Arqueoestudio S.Coop., Dirección electrónica: vmsanchez@arqueoestudio.com; No Orcid: 0000-0002-4916-1767

****Arqueoestudio S.Coop., Dirección electrónica: lorenzo.galindo@ arqueoestudio.com N $\mathrm{N}^{\circ}$ Orcid: 0000-0003-2171-1613 


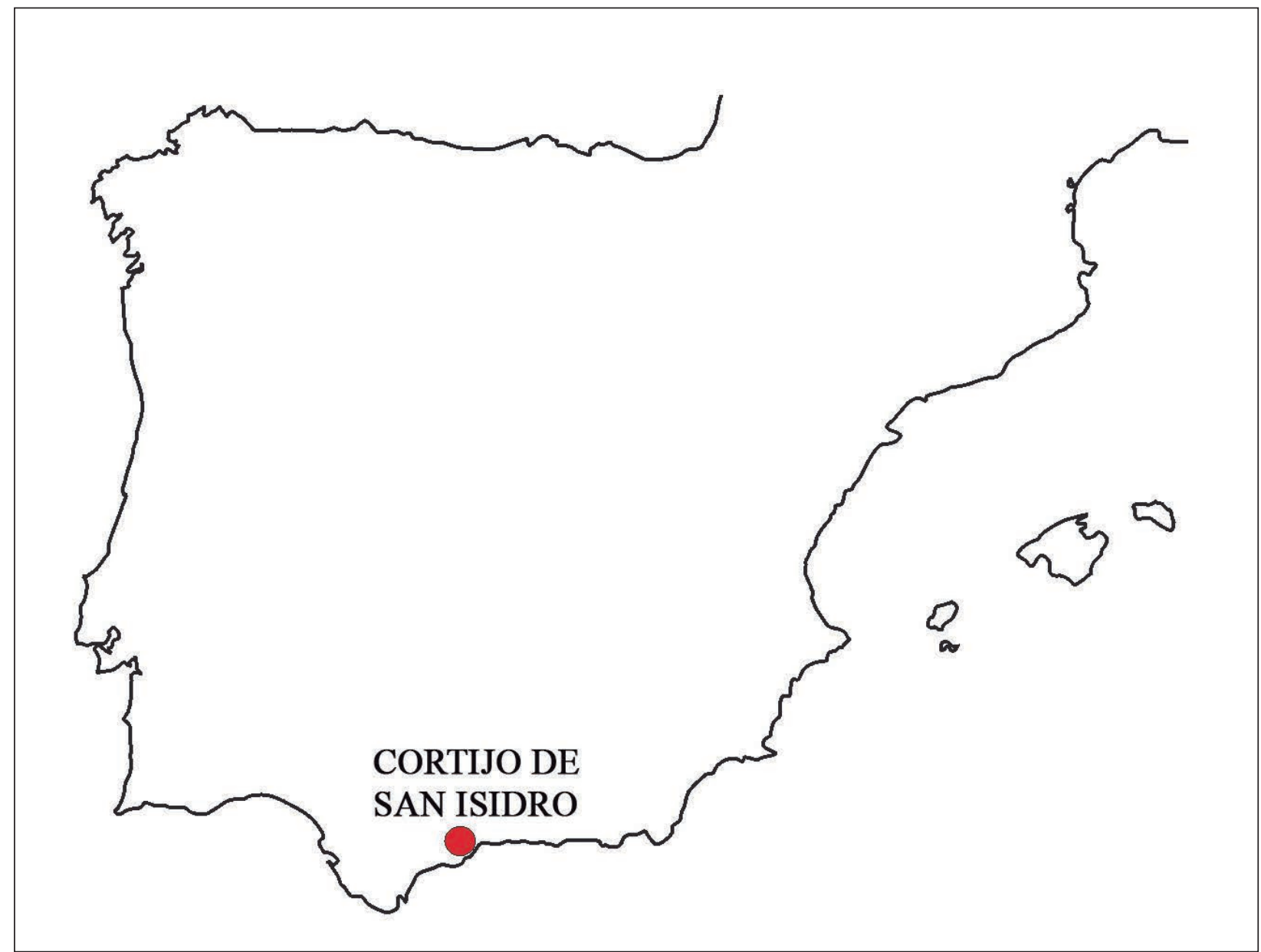

Fig. 1. Cortijo de San Isidro (Málaga) location plan.

Among the finds associated with the cremated remains of the necropolis at Cortijo de San Isidro is a small number of Egyptian(ising) seal-amulets, which will be presented here. Four stamp seals discovered until present are compared to similar finds from the Levant, Egypt and the Mediterranean. Three of them represent scarabs, the type of sealamulet especially known from Egyptian and egyptianising glyptic traditions, while the fourth is a cowroid, an Egyptian seal shape inspired by the cowrie (kauri) shell. The codes referring to typological features of the scarabs' head, wings and sides refer to the types defined by Olga Tufnell, Geoffrey $\mathrm{T}$. Martin and William G. Ward ${ }^{1}$. While acknowledging that these have been established based on scarabs of the early $2^{\text {nd }}$ millennium BC, the Tufnell-Ward typology is the basis on which additions and updates build

1 See Tufnell, Martin and Ward 1984, and for an overview of typologies and updates see Keel, 2013: xv and Ben-Tor, 2007.

2 If the subdivisions are insufficient, the general type code without further specification will be given, e.g. head type $\mathrm{F}$ instead of assigning it incorrectly to the subtypes F1, F2, and the codes will therefore be used in the description of the dorsal and lateral features of the scarabs found at Cortijo de San Isidro. Where these types have been insufficiently subdivided or are inadequate for our purposes, alternative type codes are given $^{2}$. As for the cowroid, the type classification proposed by Othmar Keel (1995: §184-195) will be followed here. The codes of the hieroglyphs engraved on the seals bases refer to the Sign List of Alan H. Gardiner 1957 (1927).

A final remark regarding terminology and conventions is that, even though all objects are finely engraved, it is unlikely they have actually been used as seals; rather, they were strung or mounted on a ring, necklace or other type of personal adornment and worn as a protective amulet, while also being appreciated for their esthetical value. They must

etc. On the other hand, general types can be further subdivided with obvious additions, e.g. the vIv back type with two lines dividing elytra receives code vIIv, and with three lines the code vIIIv, as variations on the established typological codes. 
therefore be considered as seal-amulets rather than stamp seals. As funerary amulets, they possess apotropaic and protective powers.

\section{Burial 72571 (Tomb 1):}

This cremation burial belonged to an adult male and dates to the oldest phase of the necropolis. The burial and its contents were elaborately discussed in a previous report (Navarro et al., 2016), and ceramic finds and radiocarbon dates offered a date in the late $9^{\text {th }}$ century BC for the burial. The scarab was found inside the urn, as can be seen in the CT image made previ- ously to the excavation of the container (Fig. 2). The scarab was deposited, as suggested by its position in the urn, at the same time as the human remains of the funeral pyre. The burial belonged to an adult male younger than 30 .

\subsection{Scarab 90124}

Scarab 90124 (Fig. 3) is made of grey-white steatite. It measures $16 \times 11 \times 8 \mathrm{~mm}$ and is pierced longitudinally. The scarab is preserved in excellent condition, even though part of the pronotum's base has chipped off.

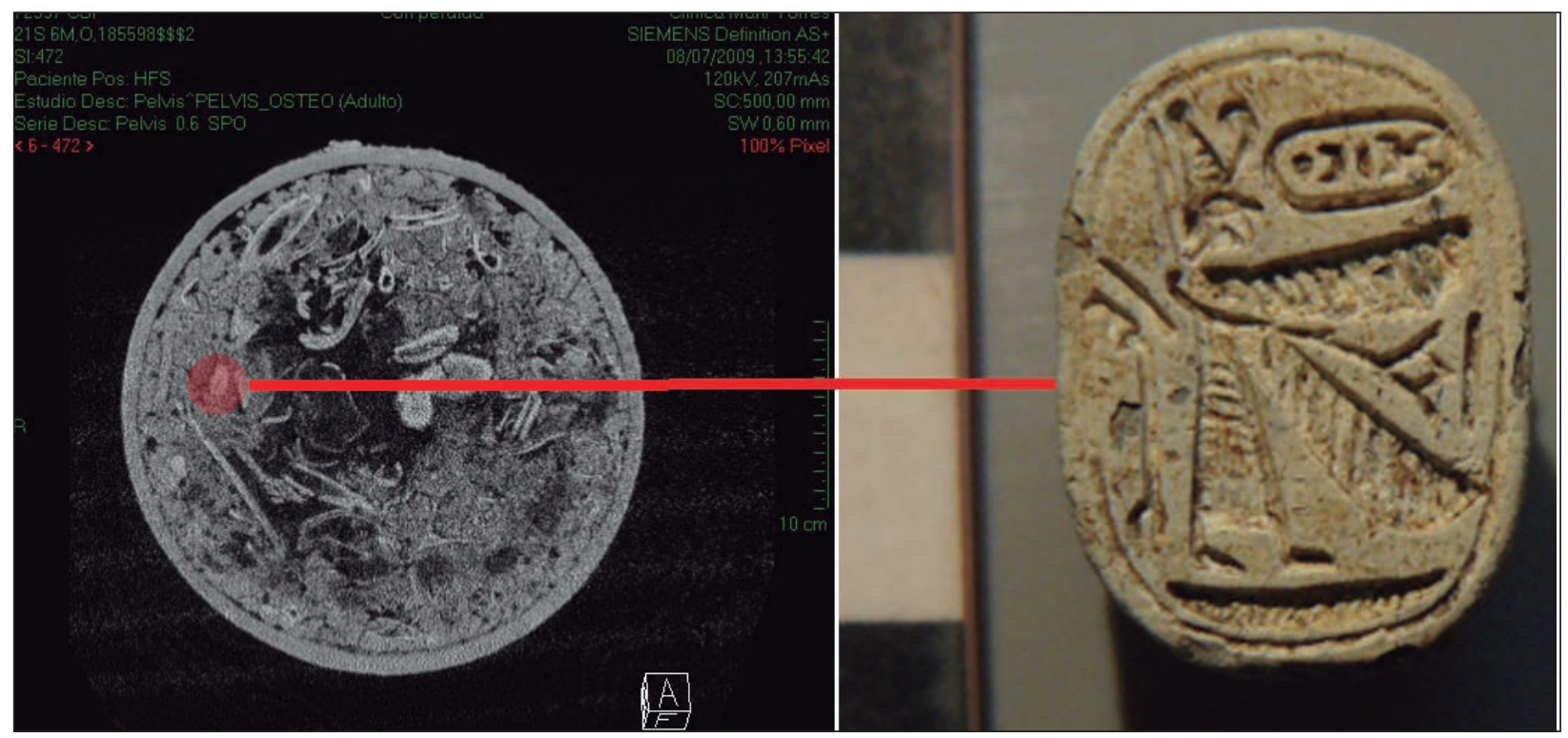

Fig. 2. Position of the scarab 90124 inside the urn burial 72571 (Tomb 1).

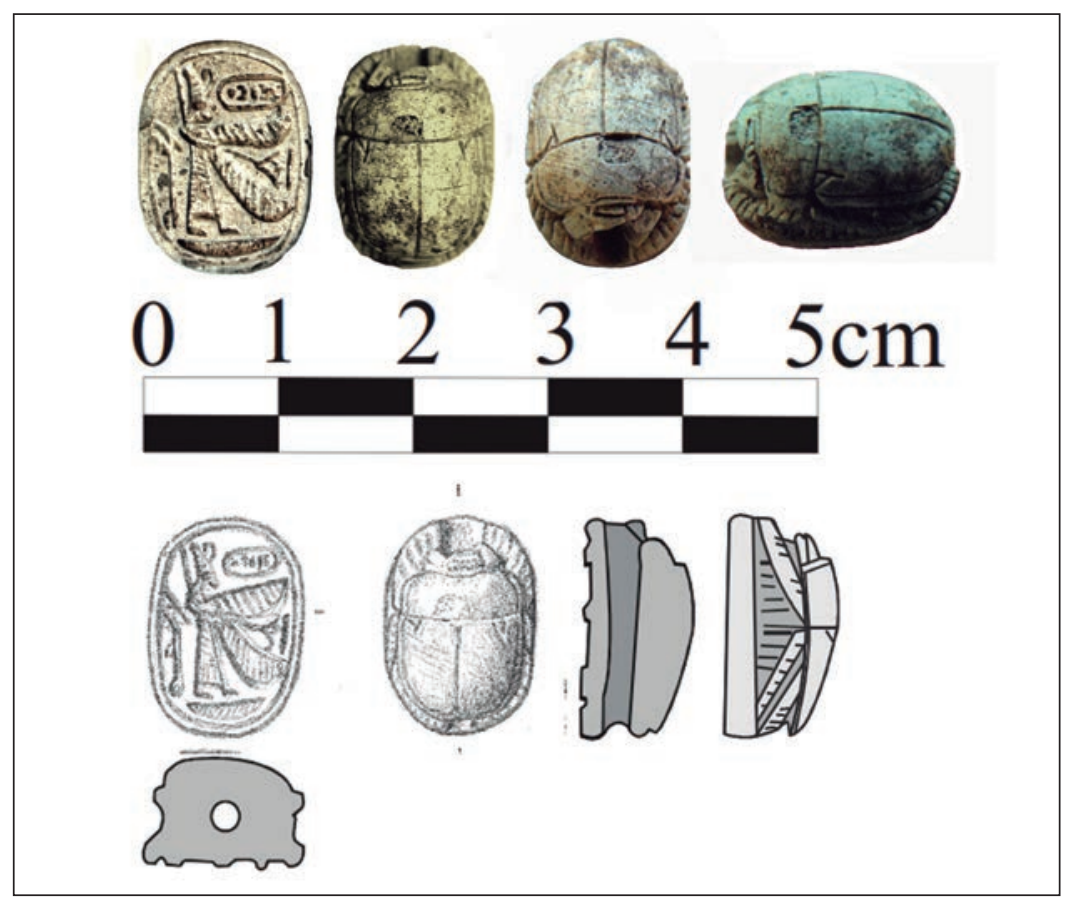

Fig. 3. Scarab 90124 


\section{Typological features}

Codes: C7 - vIv - d6

The elytra are divided by one single line, and one line separates pronotum from elytra. The humeral callosities ('shoulders') of the beetle are indicated by large V-shaped notches. The pronotum and elytra are outlined by a single line that slightly curls up at the bottom. The clypeus has chipped off, but the head and parts of the head plates are still visible. The narrow rectangular head is flanked by small eyes. The horn is not marked, nor are the head plates decorated. The sides are chip-carved. Front, mid and hind legs are decorated with fine hatching and, when seen from above, the legs surround the back of the scarab like a feathered frame.

This combination of features is mainly seen on Egyptian scarabs from the New Kingdom onwards, mainly during the Ramesside $\mathrm{XIX}^{\text {th }}$ to mid-XX ${ }^{\text {th }}$ dynasties (ca. 1295 -1150 BC) (Keel, 1995: §99-100), but also in the Third Intermediate Period (e.g. Keel, 2010b: 176-177 nr. 342) and in the XXV ${ }^{\text {th }}-X_{X V I^{\text {th }}}$ dynasties (ca. 747-525 BC) (Hölbl, 1986: 172-173). They are, however, also attested on non-Egyptian steatite scarabs, produced in the Levant. Scarabs with similar morphology have surfaced, for example in Kition and Akhziv (Clerc et al., 1976: Kit. 482; Cowie, 2004: nr. 24, 36, 40).

\section{Base design}

The design on the base of the scarab is made with linear and cut-out engraving, in combination with hatched decorations. In a vertical composition, a winged figure is standing facing right and Egyptian motifs and signs fill the empty spaces. The entire design is surrounded by a single line.

The figure is wearing the Egyptian Double Crown or pshent (Fig. 4.1), the combination of the Red Crown of Lower Egypt and the White Crown of Upper Egypt and thus representing the unified kingdom. Whereas this type of crown is generally worn by the pharaoh, the finely hatched wings identify the figure as a protective (Fig. 4.4), divine being, more specifically a celestial deity.

The winged figure is dressed in an ankle-length robe, decorated with horizontal hatching (Fig. 4.3), and holds a large water-lily (in Egyptology commonly named 'lotus') that is extended between the wings. The lotus flower is rendered by two oblique lines on either side of a bulge that is topped off by a very short stroke and a line placed perpendicularly above it (Fig. 4.4). It is very popular in Egyptian iconography and already appears in Levantine imagery of the $2^{\text {nd }}$ millennium BC, while it lives on in Phoenician art (Hölbl, 1979: 346-348). According to one of the Egyptian creation myths, it is the flower that emerges from the primeval water, the flower from which the youthful sun god (Nefertem) is born. As the lotus flower opens in the morning sun and closes again in the evening, it symbolizes renewal and regeneration (Hornung, Staehelin 1976: 96-97, 164-165) and occurs in that respect in funerary iconography. In glyptic art, for example, the lotus flower is already held by male and female human figures on Egyptian scarabs of the late Middle Kingdom, where it underscores their deceased state (Ben-Tor, 2007: 34-35). They are shown smelling the delightful scent of the blue lotus. These scarabs have inspired Levantine seal-cutters to integrate the theme on Canaanite Middle Bronze Age scarabs (idem: 148, 179), and early $2^{\text {nd }}$ millennium BC Syrian cylinder seals (e.g. Teissier, 1996: 20, 52, 56 75) on which they likely served as purely decorative motifs no longer withholding the original Egyptian symbolism (idem: 178179). In the Iron Age Levant, the lotus also re-appears in association with divine and royal figures or youthful males. It is most commonly attested in egyptianising, Phoenician art. For instance, on the Ahiram sarcophagus from Byblos a large lotus flower is held by the deceased king (Rehm, 2004), on Phoenician ivories it is seen in the hands of pharaohs, male youths and the goddesses Isis and Nephthys (e.g. Herrmann, 1986: 10, 23-24, 1043; Mallowan and Hermann, 1974: 65; Crowfoot and Crowfoot, 1938: 16 , pl. III), on the metal bowls it is held by women and goddesses (Markoe, 1985: Cy3, Cy4, Cy8) and rarely by men (Wicke, Busch and Fischer, 2010: 113, abb. 2), and on Phoenician hard stone scarabs of the Persian Period the lotus is most often associated with divinities, especially Isis (e.g. Boardman, 2003: nrs. $6 / 64,10 / 12,11 / 23,11 / 42$ ). The settings in which these lotus flowers appear and the figures they are connected with, suggest that the Egyptian meaning of renewal was conveyed by this attribute. It must be noted that the aforementioned selection of examples shows the lotus flower, but that the lily or the papyrus are equally attested.

A large was-sceptre, one of the Egyptian symbols of power, stands behind the figure (Fig. 4.3). Underneath, in exergue, a long and narrow $n b$ basket (V30, meaning 'all', 'every') on which the figure seems to be standing. When read as a hieroglyph, the $n b$ indicate all-inclusiveness of the wish or blessing expressed by the seal-amulet's design.

Finally, a simple horizontal oval is carved in the upper right corner, encompassing four highly stylised hieroglyphs that can be identified, from right to left, as: a dung beetle (L1), a horizontal stroke probably referring either to the water sign (N35) or the game board (Y5), perhaps a stylised form of the pair of upraised arms $k 3$ (D28), and a sun disk (N5), respectively with the phonetic values $h p r, n$ or $m n, k 3$, and ${ }^{\mathcal{C}}$ (Fig. 4.2). The oval reminds of the Egyptian royal cartouche but the sequence in which the signs occur does not correspond to a known Egyptian royal name, 


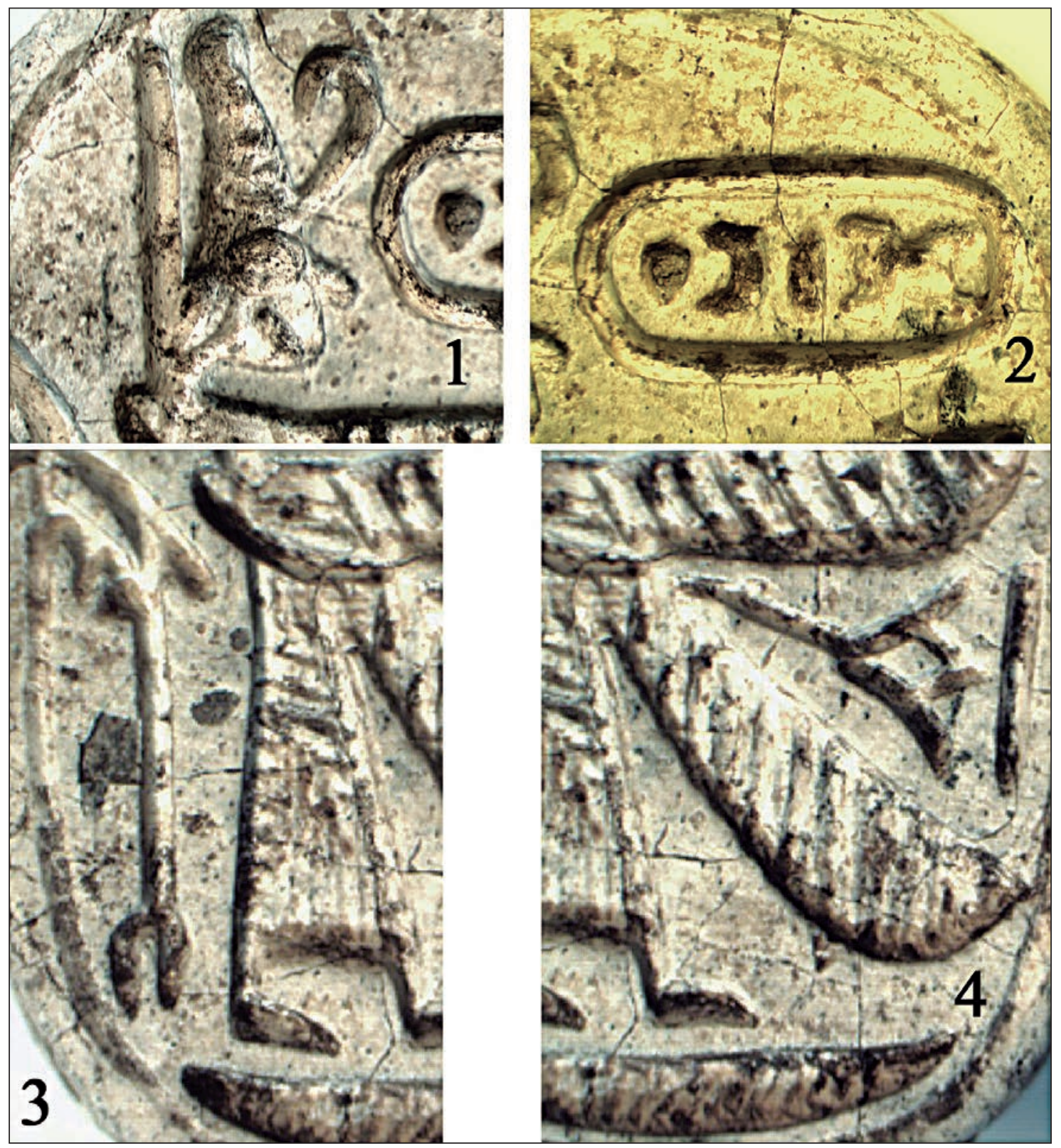

Fig. 4. Expanded view of the different elements that make up the scarab 90124.

even if it seems inspired by the throne name of the famous Thutmosis III, Mn-hpr-(k3)-r ${ }^{\mathcal{C}}$ (Jaeger, 1982: $\$ 51,1035-1041$; von Beckerath, 1999: XVIII 6.I) $)^{3}$.

The Egyptian-style iconography is imbedded in the Bronze Age repertoire, but it is egyptianising rather than Egyptian. More frequently, winged figures on stamp seals are represented with four wings. Fourwinged figures are generally male and found in Iron
Age IIB (ca. 830-700 BC) Phoenicia and Israel on ivory and bone furniture decorations or on stamp seals ${ }^{4}$. Such seals have surfaced, for example, in Dor (Keel, 2010a: 480-481 nr. 41), Dan (idem: 380-381 nr.

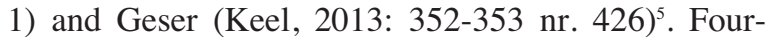
winged males are often interpreted as representing the storm and vegetation god Ba'al, shown either bareheaded or wearing a crown - often the Egyptian
3 As demonstrated by Bertrand Jaeger (1982), the presence of the name $M n$ - hpr-r $r^{\mathcal{L}}$ on scarabs is no dating criterion on itself as Thutmosis III was worshipped posthumously and his name occurs on seals long after his reign. Together with the name Mny, it is source of inspiration for many pseudocartouches in Phoenician art.
4 Some examples are enumerated in Keel and Uehlinger, 1992: \$121 and Gubel, 1993: 124.

5 For unprovenanced seals, see e.g. Avigad and Sass, 1997: nrs. 715, 730, 791, 844, 1020, 1036, 1087, 1092, 1119, $1134,1147,1154,1156,1165$. 
Double Crown. While Iron Age depictions show him with four wings, in the Late Bronze Age Ba'al had one pair of wings, or none at all ${ }^{6}$. The doubling of the pair of wings in the Iron Age IIB may point to a development during which the celestial aspect and thus the omnipresence of the god was emphasized (Keel and Uehlinger, 1992: §121). However, Ba'al is generally bearded and wears a short kilt, whereas the figure on scarab 90124 is beardless and has a long garment. Iconographic comparanda are therefore taken into account in an attempt to identify the winged figure.

Adequate parallels are the two-winged figures holding lotus or lily flowers engraved on $9^{\text {th }}-8^{\text {th }}$ century BC Phoenician (or rather 'South Syrian' cf. Winter, 1981) ivory plaques from Samaria (Crowfoot and Crowfoot, 1938: pl. IV 3a) and Arslan Tash (Winter, 1981: pl. VII nrs. a and c). In glyptics, a young winged male (Ba'al?) is seen holding a lotus flower - though not wearing a crown - on an $8^{\text {th }}$ century BC Israelite name seal from Carthage (Avigad and Sass, 1997: nr. 185) and on an oval plaque from Halif (Keel, 2013: 532-533 nr. 4) where he is empty-handed. Most interestingly, steatite scarabs dated to the end of the Late Bronze Age and the early Iron Age showing a winged figure on horseback argue for an identification of the crowned winged figure on scarab 90124 as the goddess Astarte. Such equestrian winged divinities wearing a headdress that resembles the Egyptian Double Crown had been interpreted as representations of Seth-Ba'al, but more recently it has been argued that they may be identified as Astarte or, less likely, Anat (Cornelius, 2004: 44, 73, 85, cat. 4.22-26). The Phoenician Iron Age II production in steatite also include scarabs with the two-winged figure holding ostrich feathers or objects (e.g. Boschloos, 2014b: 1516). Finally, mention should also be made of the wellattested depictions of a winged goddess, commonly identified as Isis, on late Phoenician scarabs $\left(6^{\text {th }}-4^{\text {th }}\right.$ century BC) in steatite or semi-precious stones, already mentioned above. She is generally portrayed with one pair of outstretched wings and with a sun disk above her head, sometimes bareheaded (e.g. Boardman, 2003: pl. 9-11; Nunn, 2000: taf. 49, 51; Ward, 1970), though it is not uncommon in $8^{\text {th }}-4^{\text {th }}$ century Phoenician glyptic art to see divine figures wearing the Egyptian Double Crown ${ }^{7}$. Some of these examples show her holding one or two flowers, either lotus, papyrus or lily. The theme of the winged Isis holding flowers lives on in Hellenistic times, for example on signet rings ${ }^{8}$.

6 On Ba'al and Seth-Ba'al in Levantine and Egyptian iconography of the Late Bronze Age, see: Cornelius, 1994; Schroer, 2011: 54, nrs. 899, 902-904.

7 For example, Avigad and Sass, 1997, nrs. 1036, 1092,
The iconography and style attribute this scarab to a Levantine, more specifically Phoenician origin because of the strong egyptianising style. Standing winged figures are not uncommon themes on seal-amulets, but they belong to the Levantine rather than to the Egyptian sphere. It is therefore highly unlikely the signs in the oval are meant to be read as an inscription or name; they are rather to be understood as a pseudo-inscription, a Phoenician adaptation of a common Egyptian motif. As for the winged figure, it can only be identified with certainty as a protective divinity. This scarab dates well before the examples with the winged Isis on late Phoenician hard stone scarabs, which announce the final phase in the development of this theme. Comparanda in other minor arts, more specifically in $9^{\text {th }}-8^{\text {th }}$ century Levantine ivory carving, indicate that the scarab is to be placed around that time frame, and scarabs showing an equestrian deity with Egyptian Double Crown, though not associated with the flower, suggest that the figure may represent the Levantine Astarte, or even Anat or Seth-Ba'al.

\section{Burial 90111 (Tomb 2):}

Cremation burial 90111 belongs to the second phase of the necropolis. Inside the funerary urn a scarab was found (Fig. 5), accompanying the male deceased of approximatively 40 to 60 years old. The fact that the scarab was found among the cremated remains of the individual, indicates that it was deposited inside the run at the same time as the remains from the funeral pyre. Based on the ceramic evidence, this burial is also dated in the late $9^{\text {th }}$ century BC.

\subsection{Scarab 90129}

This small scarab is made of grey-white steatite and measures $14 \times 10 \times 7 \mathrm{~mm}$. It is pierced longitudinally and preserved in excellent condition (Fig. 6).

\section{Typological features}

Codes: F-vIIIv - d6

Three lines divide the elytra and two lines separate elytra from pronotum. Wings and pronotum are outlined by a single line. V-shaped notches indicate the humeral callosities. The head is semi-circular to rectangular, with a semi-circle at its base, and round eyes are marked on both sides. The head plates are straight but finely decorated with hatching. The clypeus is dented. The sides of the scarab are chip-carved and fore, mid, and hind legs are decorated with hatching. Fore and mid legs are separated by two vertical strokes.

1147, 1165

8 E.g. a Hellenistic finger ring found in Carthage published in Boardman, 2003: pl. 64 nr. R.50. 


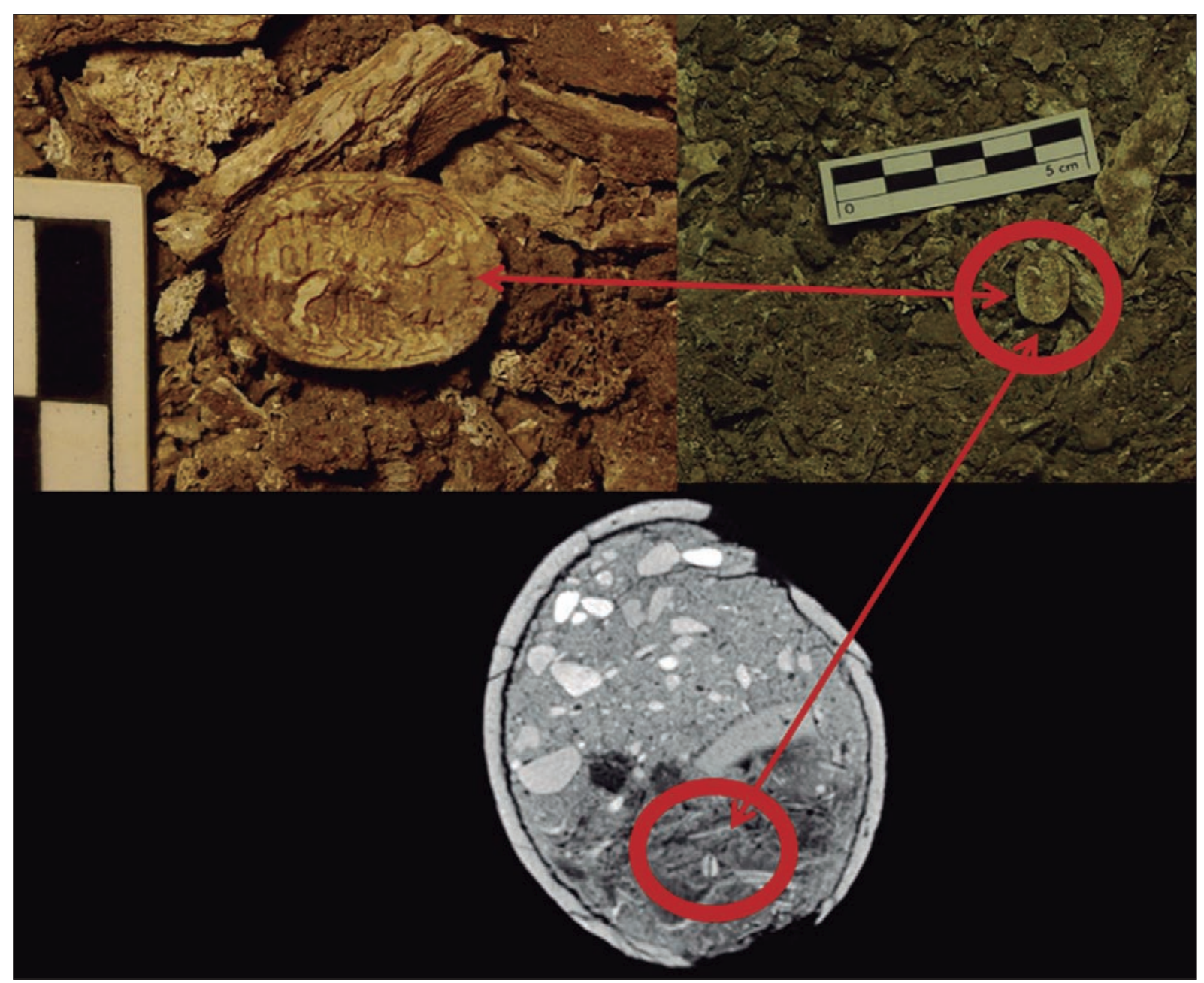

Fig. 5. Location of the scarab 90129 inside the urn burial 90111 (Tomb 2).

The best typological parallels are a faience (or glazed steatite ?) scarab from the oldest phase $\left(9^{\text {th }}\right.$ century BC) of Akhziv's family tomb T.N.19, a Phoenician steatite scarab from the Beirut art market (Buchanan and Moorey, 1988: pl. IX nr. 281), and a Phoenician inscribed steatite scarab from Akko that epigraphically and iconographically dates to the $9^{\text {th }} / 8^{t_{\text {th }}}$ century BC (Keel, 1997: 53-537 nr. 19). These are typologically identical to scarab 90129, indicating they were manufactured by the same seal cutter or at least in the same workshop. A Sidonian origin has moreover been suggested for the Akko scarab, based on the presence of a ramheaded sceptre held by one of the figures (Gubel, 2001: 41). In conclusion, the date offered by the Akhziv tomb places their production period in the $9^{\text {th }}$ century BC and the workshop is probably to be located in the Sidonian or Tyrian region.

9 Dated by the excavators to the $10^{\text {th }}$-early $9^{\text {th }}$ century $\mathrm{BC}$, but see Boschloos, 2014b, 11 and Boschloos, 2018, on the scarabs from this phase and its chronology. The design on

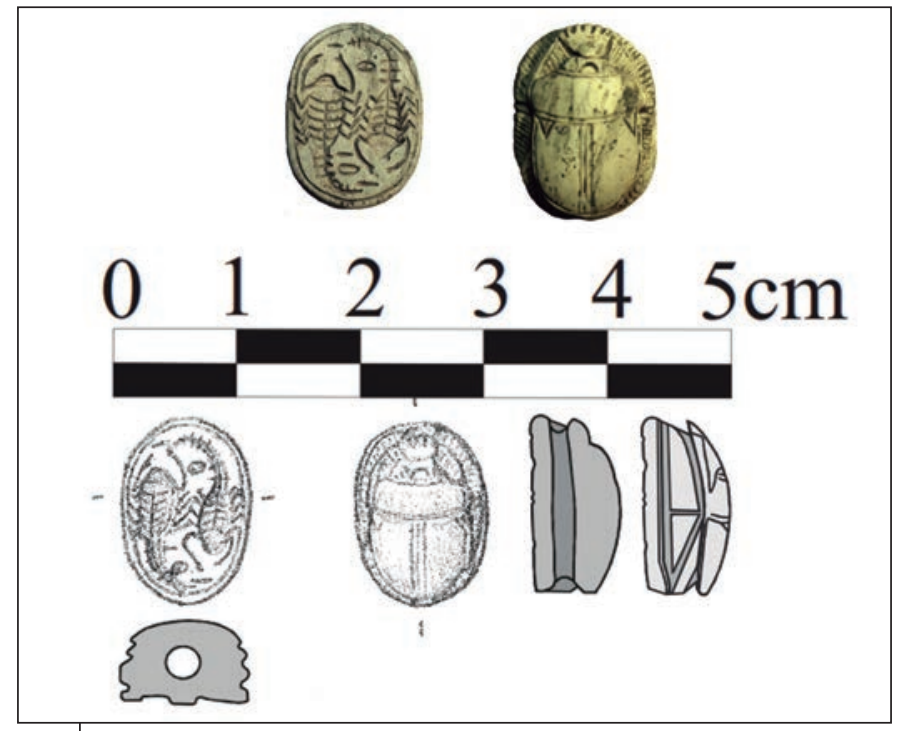

Fig. 6. Scarab 90129. the base of this scarab is reminiscent of Canaanite Middle Bronze Age models and includes an anra-like sequence. 


\section{Base design}

Linear and cut-out engraving is used to decorate the base of the scarab. Two scorpions are placed têtebêche and between them are two small ovals and three shorts strokes (Fig. 7). The entire design is surrounded by a single line.

Animals tête-bêche first appear on Egyptian sealamulets during the Old Kingdom (VI ${ }^{\text {th }}$ dynasty, ca. 2350-2180 BC) (Wiese, 1996: 81-82, 87-88) and decorate scarab bases as early as the early Middle Kingdom. The concept is, however, taken from Early Bronze Age Syro-Palestinian cylinder seals (early $3^{\text {rd }}$ millennium BC) and is therefore Levantine in origin (Collon, 2005: 24). Most common are crocodiles, lions, scorpions and caprids. Both Egyptian Middle Kingdom scarabs and the already present iconographical traditions in the Levant facilitate the transmittance of the idea to Canaanite Middle Bronze Age scarabs (Ben-Tor, 2007: 32). Compositions with animals tête-

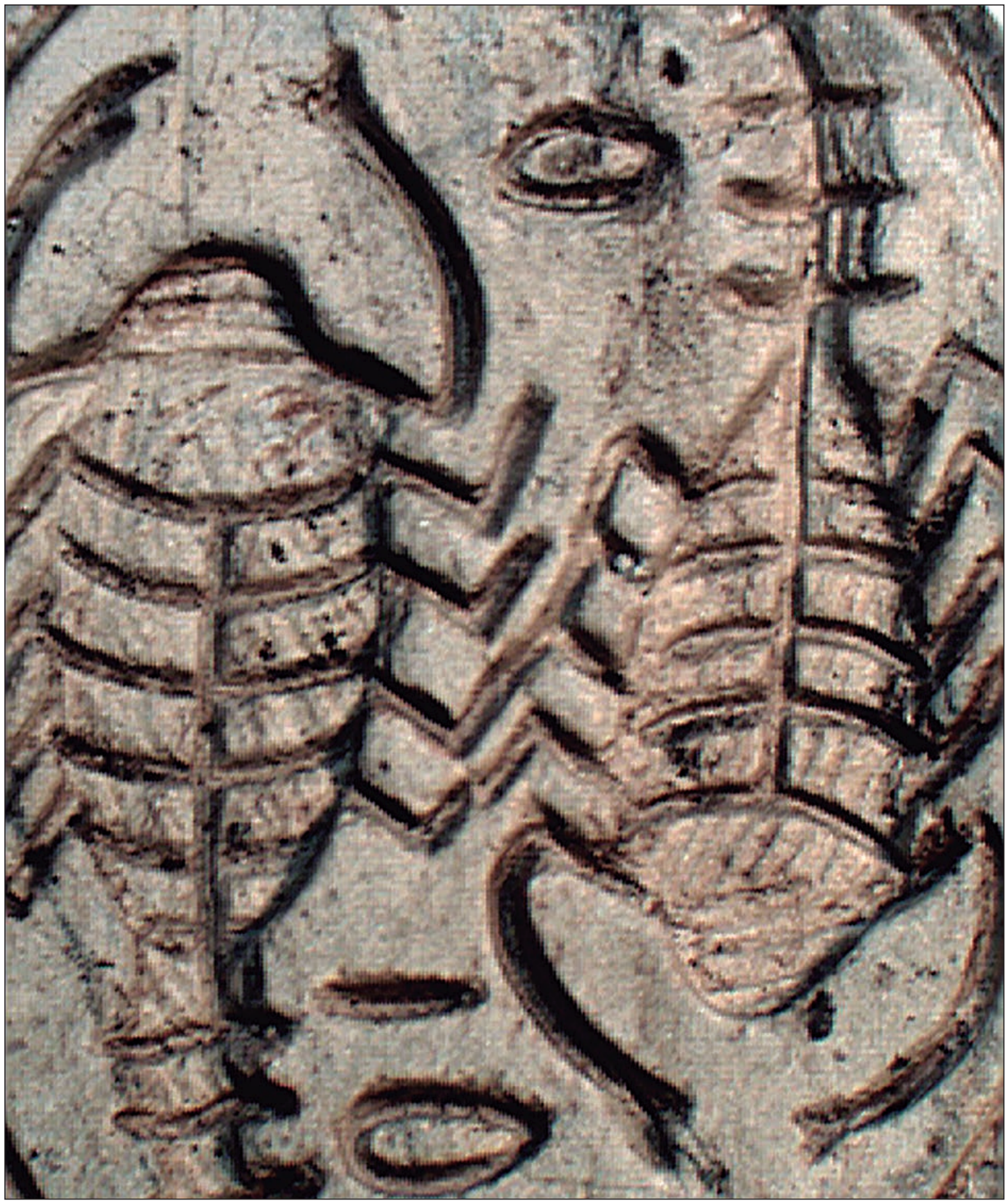

Fig. 7. Detail from scorpions of the scarab 90129. 
bêche still occur on scarabs of the second half of the $2^{\text {nd }}$ millennium BC, and until the end of scarab production - though much less frequently - both in Egypt and the Levant $^{10}$

For the scorpion on Egyptian stamp seals, examples are numerous but they seemingly do not date before the second half of the $2^{\text {nd }}$ millennium BC. From the early $18^{\text {th }}$ dynasty onwards, a single scorpion, often accompanied by a nfr hieroglyph (F35), meaning 'good, perfect', decorates Egyptian stamp seals (e.g. Hayes, 1959: p. 87 bottom right; Régen and Soukiassian 2008: nrs. 148 and 291; Tufnell et al., 1984: fig. 22 nr. 4; von Pilgrim, 1996: abb. 136 nr. 1). Scorpions tête-bêche are introduced in mid-18 ${ }^{\text {th }}$ dynasty and are especially popular on Ramesside sealamulets (e.g. Petrie, 1896: pl. XV nr. 56; Quibell, 1898: pl. XXX nr. 31). These New Kingdom sealamulets have also been found outside Egypt, for example in Tell el-Far'a South (Keel, 2010b: 338-339 nr. 729), Tel Gamma (Keel, 2013: 48-49 nr. 110), Beth Shean (Keel, 2010a: 108-109 nr. 28), Akko (Keel, 1997: 606-607 nr. 215), Byblos (Dunand, 1954: nr. 8675), Mari (Jean-Marie, 1999: 44-45, 119, pl.29). Among the Egyptian seal-amulets of the mid-1 ${ }^{\text {st }}$ millennium showing animals tête-bêche (cf. supra), some show the pair of scorpions, attesting to a renaissance of the scorpion as main motif in the Egyptian tradition (e.g. Griffith, 1923: pl. LII nr. 13, pl. LIV nr. 16).

In ancient Egypt, this arachnid had two opposite not necessarily contradicting - meanings. It is of course known to be a dangerous, poisonous creepy crawler from the desert that needs to be approached with caution and in this capacity becomes a symbol of danger and threats to one's well-being. On the other hand, when the scorpion is 'on your side', it will help to ward off other dangers, serving as protection against all sorts of enemies. Equally apotropaic is the connection with motherhood and motherly protection, mirrored on the fact that the female scorpion carries the off-spring on her back in the first phase after hatching to protect the scorplings (Hornung and Staehelin, 1976: 131-133; Stoof, 2002). As for its meaning outside Egypt, in the ancient Near East, the scorpion also protects against evil and danger. It mainly symbolizes fertility (Zernecke, 2008) and on stamp seals is therefore also found associated with the cow or caprid suckling her young, with female deities (viz. the mother goddess) or in the hands of 'the Lord of the animals' (Keel and Uehlinger, 1992: $\$ 85,92-93$ and 172). These date to the Iron Age and show compositions with the scorpion in a secondary position; it rarely appears as the main

10 Especially on Egyptian scarabs of the $\mathrm{XXV}^{\text {th }}-\mathrm{XXVI}^{\text {th }}$ dynasties (e.g. Petrie, 1888: pl. VIII nr. 30; Griffith, 1923 : pl. XLV nrs. 22-23, pl. XLVI nrs. 9, 16, pl. XLVIII nr. 20, pl. L nrs. 1-2, pl. LII nr. 13, pl. LIV nr. 16), with a preva- subject on non-Egyptian seal-amulets. The single scorpion occasionally features on scarabs from Naukratis (e.g. Hölbl, 1979: nr. 1057; Petrie, 1886: pl. XXXVII nrs. 8-10) and from the late Phoenician-Punic west (e.g. Boardman, 2003: 43/34; Vercoutter, 1945: nrs. 639-640), whereas some late Iron Age I- Iron Age II stamp seals with scorpions tête-bêche from the Levant (Keel, 2010a: 102-103 nr. 15, 240-241 nr. 53) may be situated between the Egyptian and Phoenician developments of this theme.

\section{Burial 72510 (Tomb 4):}

Stratigraphically, Tomb 4 belongs to the second phase of the necropolis, like Tomb 2. This burial consists of a ceramic container with the cremated remains of an individual of which sex or age have not yet been determined. The urn was placed inside a small hole, on top of two seal-amulets: a scarab and a cowroid. So, contrary to the find spot of the previous seal-amulets, they were deposited outside of the funerary container (Fig. 8). Tomb 4 is dated in the late $9^{\text {th }}$ century BC.

\subsection{Scarab 72516a}

This scarab is made of grey-white steatite. It measures 16 × $11 \times 8 \mathrm{~mm}$ and is pierced longitudinally. The scarab is badly preserved, with the entire back of the scarab gone and only the lower sections of the legs and the base plate with the engraved design preserved. A black concretion is visible at the top of the base, as a result of its processing during the funeral (Fig. 9).

\section{Typological features}

Codes: C7 -vIv - d6

The back is damaged, but a single line that divides the elytra can still be discerned at the bottom. Similarly, on the left side of the back, a V-shaped indication of the left humeral callosity and the beginning of the line that separates elytra and pronotum are visible. The elytra are outlined by a single line that curls up at the bottom. The long narrow head is flanked by two eyes and the horn is indicated. The head plates are represented and the large clypeus has dented extremities. The sides of the scarab are chipcarved and all legs are decorated with hatching. When seen from above, they form a feathered frame around the scarab, a feature particularly common on Egyptian Ramesside scarabs and known for the $1^{\text {st }}$ millennium BC as well (cf. supra).

lence for crocodiles, but also in Naukratis (e.g. Hölbl, 1986: taf. 123 nr.4; Petrie, 1886: pl. XXXVII nr. 11). For rare examples in Phoenician glyptic art, see e.g. Boschloos, 2014b: pl. 4.5 and examples with scorpions cited below. 

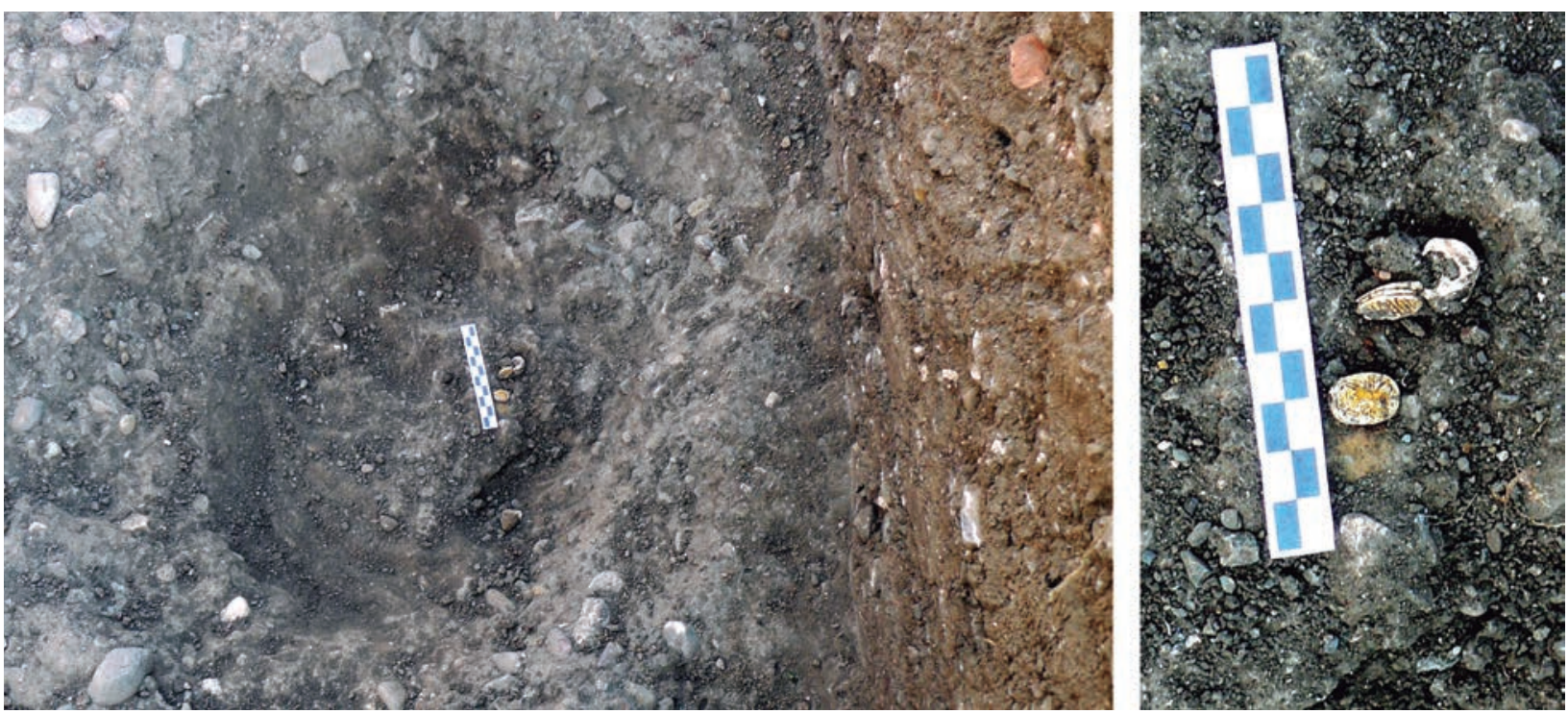

Fig. 8. View of the location of the seal-amulets deposited outside of the funerary container burial 72510 (Tomb 4).

\section{Base design}

The design on the base of the scarab is made with linear and cut-out engraving, to a small extent combined with hatched decorations. In a vertical composition, a standing figure wielding a mace is holding a prisoner by the hair. Egyptian hieroglyphs fill the surrounding spaces. The entire design is surrounded by a single line.

The smiting figure, dressed only in a short kilt (šendyt) with a lion's tail as belt, wears a short wig or plain head cloth, a broad collar, but holds no additional attributes except for the mace. The captive is proportionally smaller, turned towards him and raises both arms in despair. The bent knees of the prisoner suggest that the rest of his body is turned in the opposite direction (Fig. 10.4), away from the vanquisher. The theme is well-known in Egyptian art as within its sphere of influence and represents the triumphant pharaoh ${ }^{11}$. Traditionally, the king, in a striding position, stands over his enemy or enemies, whom he holds by the hair in one hand while wielding a weapon in the other. The prisoners are usually Nubian, Libyan or Asiatic. In case of a single captive, the head is turned towards his vanquisher while the rest of the body is turned away, though in some cases, he faces the vic- torious ruler in full length. When several vanquished enemies are shown, the variations are more elaborate. Generally, a falcon-headed deity (probably the war god Montu) holding a hpš sword or scimitar aloft accompanies the sovereign, symbolising the divine approbation of pharaoh's victory over his enemies.

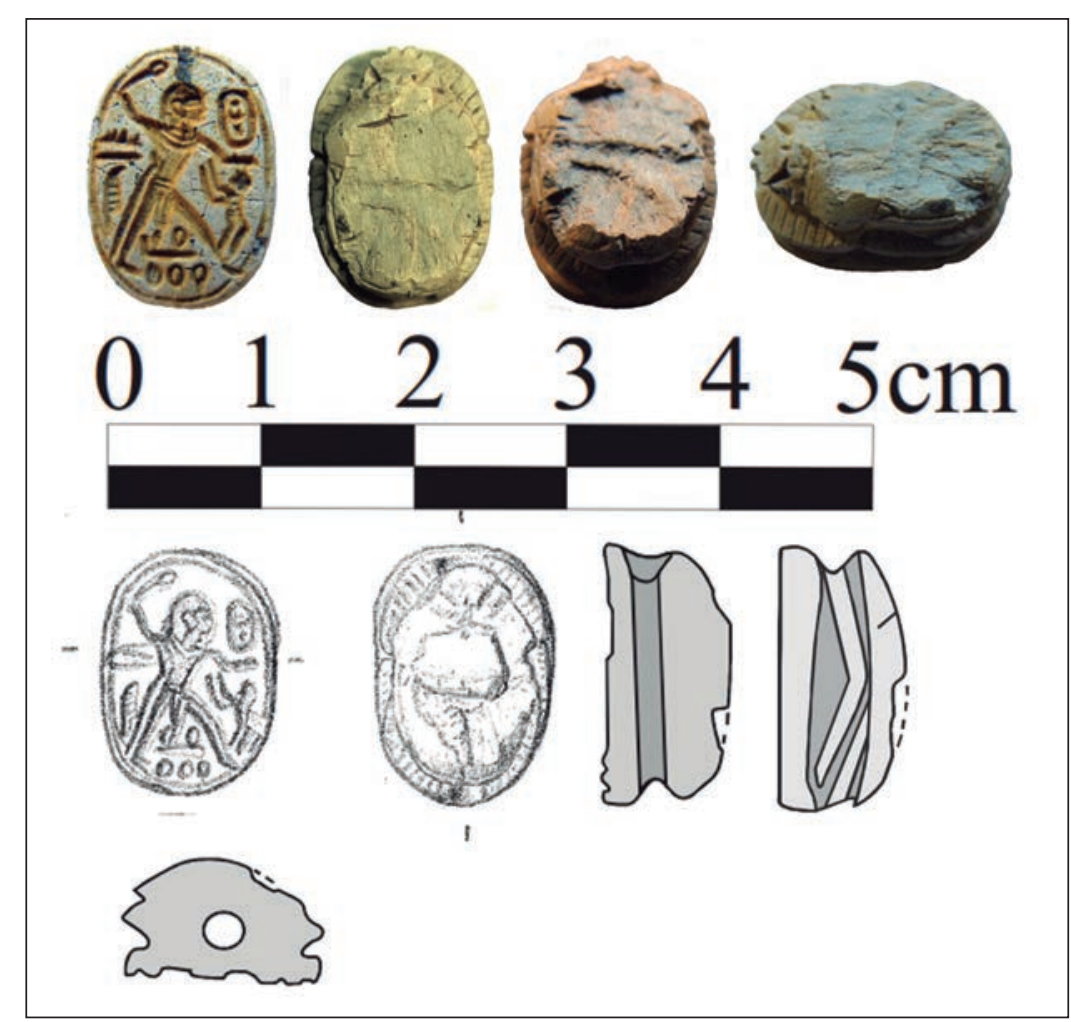

Fig. 9. Scarab 72516a.

11 For the impact on Phoenician art see Markoe, 1985: 45-47 and notes, and more recently Gubel, 2012. 
Considering the horror vacui that generally characterizes these compositions on seal-amulets, the fields surrounding the figures are filled with signs and motifs, in most cases mentioning the name(s) and title(s) of the king, and/or blessings. On the scarab from Cortijo de San Isidro, three hieroglyphs behind the pharaoh's back - from bottom to top: the reed $j$ (M17), the water $n(\mathrm{~N} 35)$ rendered by a simple horizontal line, and the game board mn (Y5) - form the name jmn (Fig. 10.1), summoning the divine protection of the sun god Amun. An oval in the upper right corner encompasses three signs of which only one can be identified with certainty, the circle of the sun disk $r^{c}$ (N5). The central sign does not resemble any Egyptian hieroglyph ${ }^{12}$ and a rectangular sign at the bottom is also problematic, indicating that the oval represents a pseudo-cartouche (Fig. 10.2). That the sign combinations on the scarab are not meant to form meaningful inscriptions is furthermore supported by the motifs between the pharaoh's striding legs. For the combination of three circular motifs (N33/W24?) and a cornersign that could refer to the arm ( $r$ ) dj holding a round object (D37/D38/D39?) no parallels can be cited here $^{13}$, nor can a reading for the combination be offered (Fig. 10.3).

The design of the smiting Pharaoh is abundantly attested in Egyptian art, extending as far back as the Early Dynastic Period (end of the $4^{\text {th }}$ millennium $\mathrm{BC}$ ). In their preference for an impressive, propagandised iconography to commemorate their conquests (even if they were not always as successful as they were made out to be) the New Kingdom rulers stimulated the use and development of such motifs as the Smiting Pharaoh which, consequently, became frequent in the repertoire of Egyptian iconography during these dynasties, culminating in Ramesses II long reign. While the components of the composition remain practically unchanged until the $\mathrm{XIX}^{\text {th }}$ and $\mathrm{XX}^{\text {th }}$ dynasties, it is undoubtedly during this period of military expansion that the motive became differentiated in various ways (Swan Hall, 1986). The smiting stance is adopted by Reshef and Ba'al and the Smiting God thus joins the theme of the Smiting King in the iconographic repertoire of the Iron Age Levant (Bisi, 1992; Cornelius, 1994: 255-259; Gubel, 2012; Markoe, 1985: 45-47). From the $8^{\text {th }}$ century onwards, the pharaoh-like figure features in Phoenician glyptic, inspired by or at least closely connected to the theme on Phoenician ivories and metal bowls (Boardman, 2003: nrs. 18/4-13, 18/x4; Gubel, 2012: 28-30).
Numerous scarab seals published so far feature a representation of the smiting pharaoh, generally wearing the Blue, sometimes the Red or the Double Crown, respectively indicative of the king in his quality of military leader or king of Lower and Upper Egypt. Adequate parallels for the composition with the uncrowned pharaoh, as seen on the scarab from burial 72510, however, are all but numerous. The most interesting is a scarab kept in Basel (Hornung and Staehelin, 1976: nr. 308), showing the pharaoh wielding the shm or ${ }^{c} b 3$ sceptre (S42) and wearing the šwty or Two (ostrich) Feathers crown. Between his legs is a stylised winged sun disk and the empty fields around show the hieroglyph $n t r(\mathrm{R} 8)$ and a large ostrich feather, $m 3^{c} t$ (H6), combined meaning 'the just/righteous god'. Both the general style and the use of hieroglyphs to fill the field are comparable on both scarabs. It is therefore very likely that scarab 72516a is an imitation of an Egyptian Ramesside model, but the meaningless combinations of signs and the incorrect rendering of hieroglyphs indicate that it is of non-Egyptian origin. It is not difficult to see in the composition on a late Phoenician cornelian scarab from the former Morrison collection (Boardman, 2003: 18/x4) the Nachleben of this early Phoenician interpretation.

\subsection{Cowroid 72516b}

This seal-amulet imitates the cowrie shell and is made of grey-white steatite. It measures $16 \times 8 \times 7 \mathrm{~mm}$ and is pierced longitudinally. The cowroid is in good condition, except for a damaged part of the lower base plate where the piercing has become visible. Edges have chipped off in the lower right and upper left parts of the base (Fig. 11).

\section{Typological features}

As early as prehistoric times, cowrie shells and their imitations in stone or faience are in general associated with fertility, women and children - even though cowroids were also found in male burials -, because the ventral opening of the shell shows similarities with female genitalia (Golani, 2014; Schroer, 2015: 399-408). Cowroids are dated by the iconography and style of the engravings on the base, and Othmar Keel additionally uses length-width proportions to chronologically arrange types, all the while acknowledging that exceptions to the rule are recurrent in the Ramesside Period. The cowroid becomes less popular during the $1^{\text {st }}$ millennium BC (Stoof, 2015: 93).
12 There is some resemblance with the jackal head wsr (F12), but the pole on which it stands is absent.
13 For the three circles, cf. the meaningless combination of signs on a scarab from Kition in Clerc et al., 1976: Kit. 821. 

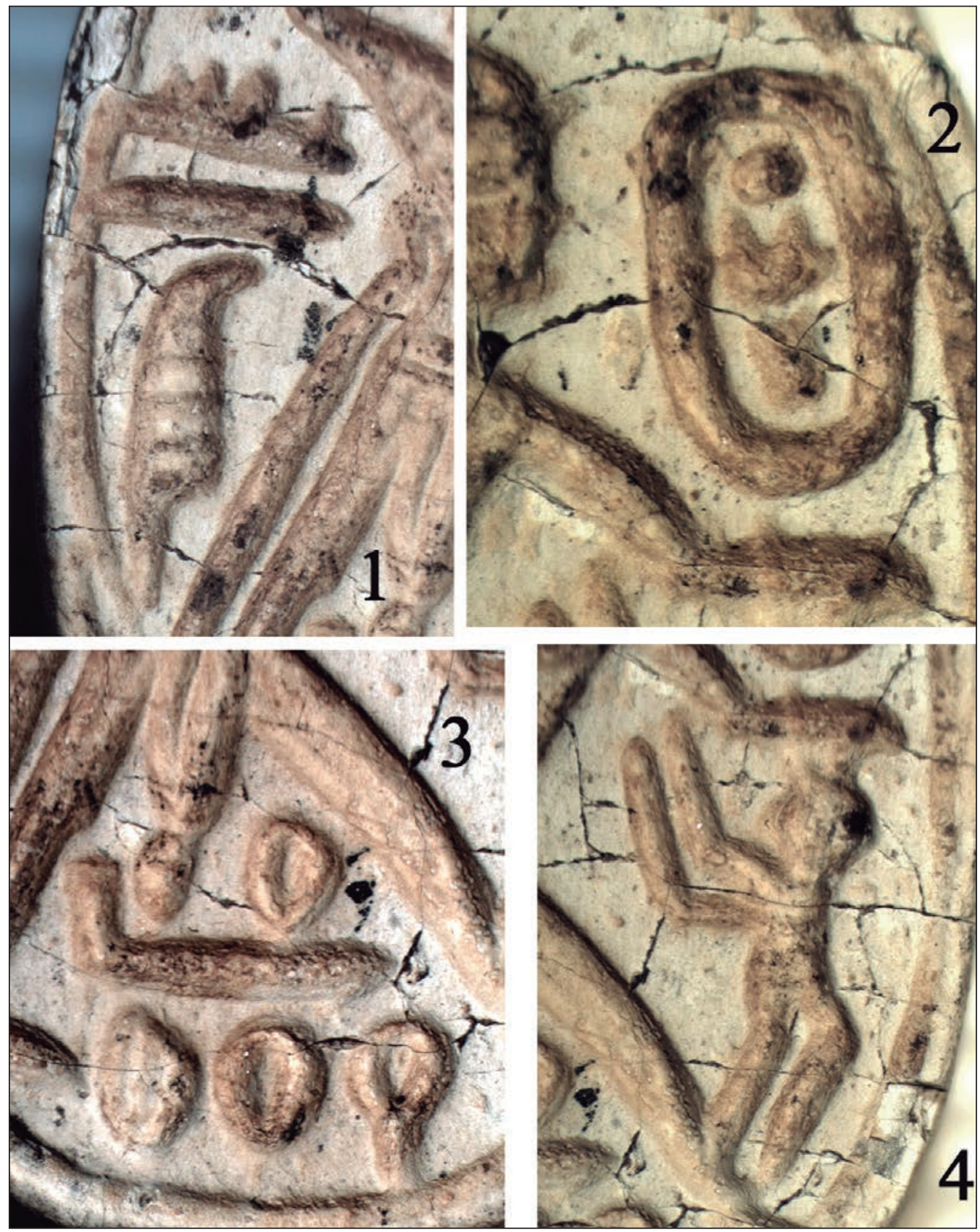

Fig. 10. Expanded view of the different elements that make up the scarab 72516a.

This cowroid can be classified in his Type III (Keel, 1995: §185), encompassing cowroids decorated with an all-round rope border (Schnurmuster or Kerbband) and the most common type of cowroid. The length-width proportions ${ }^{14}$ of 1,8-2:1 are considered by Keel to be characteristic for Type III cowroids of the Late Bronze Age IIA/mid-to late $18^{\text {th }}$ dynasty (14 ${ }^{\text {th }}$ century BC) and are applied to some Ramesside cowroids. In her - unfortunately barely illustrated - volume on cowroid stamp seals, Magdalena Stoof similarly mentions the occurrence of this type from the Middle Bronze Age/Second Intermediate Period to the Late Period (Stoof, 2015: 43-45), i.e. from the $17^{\text {th }}$ to the early $6^{\text {th }}$ century BC. Finally, the lengthheight proportions of 2,3-2,5:1 do not correspond with the usually higher profile Keel observes on Ramesside cowroids, namely at 2:1 (Keel, 1995: $\S 192-193)$.
14 A range of proportions is given, the first calculated with the given measurements and the second based on the photo- graphs, to exclude any discrepancy. 


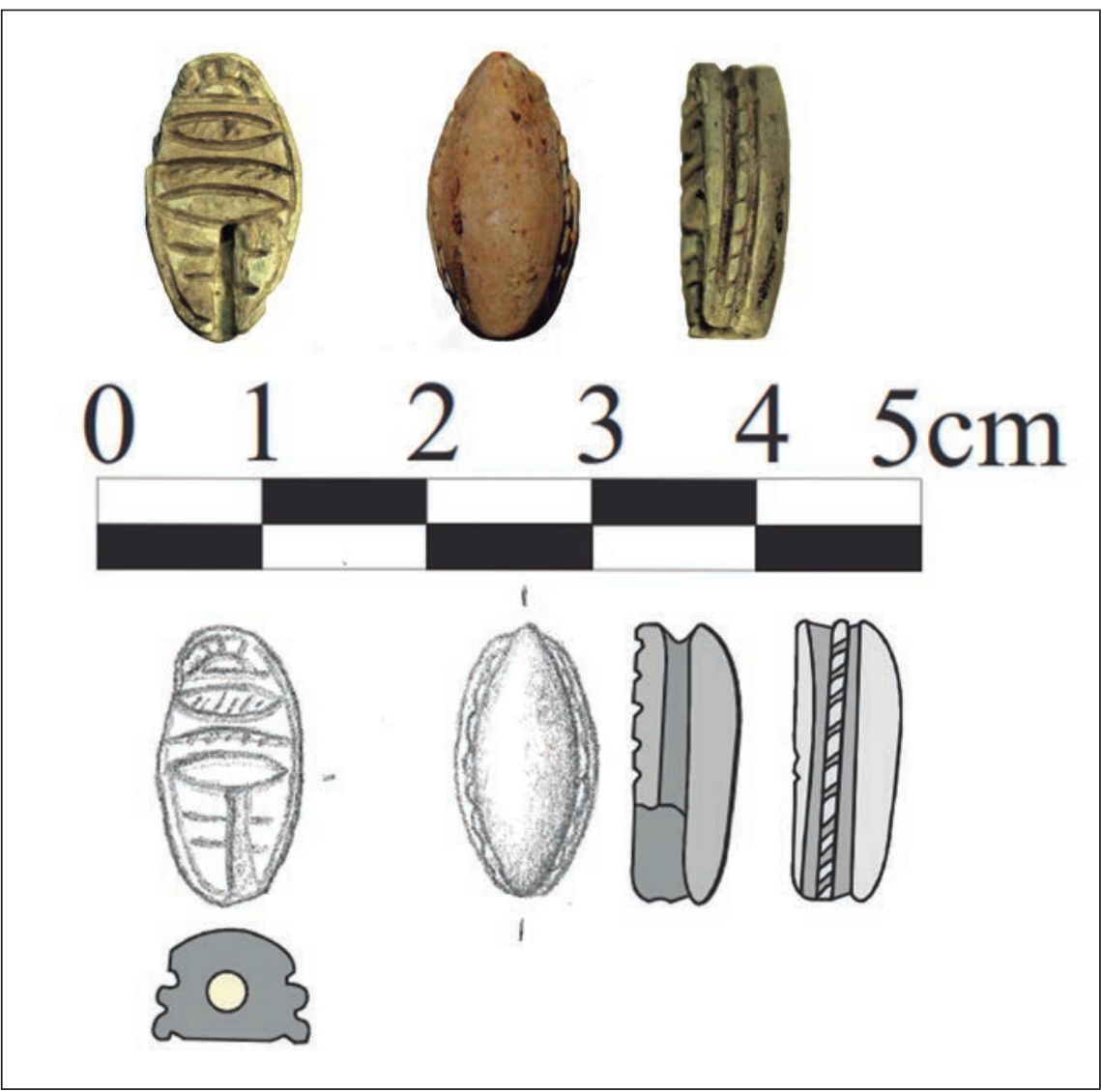

Fig. 11. Cowroid 72516b.

\section{Base design}

The base design is linearly engraved, with some hatched decorations. Five to six hieroglyphs, each different, are engraved one on top of the other and there is a single line surrounding the inscription.

The second and fourth signs are alike, but only one is filled with hatching. The lower two signs are damaged and resemble straight horizontal stokes. From top to bottom the following hieroglyphs may thus be identified: the hill with sunrise $h^{c}(\mathrm{~N} 28)$, the mouth $r$ (D21), a horizontal stroke diagonally hatched and probably referring to the water sign $n(\mathrm{~N} 35)$, again the mouth, and the two horizontal strokes. Given the fact that the two $r$ are rendered in a different manner argues against the manufacturing by a workshop or seal-cutter familiar with these signs. Since the combination of signs does not form a meaningful inscription, it is very likely the sequence is not meant to be read and deliberately represents a pseudo-inscription, or is a poor imitation of a particular model. The mouth and water signs are frequently encountered together, on Egyptian and Levantine scarabs, in combination with a fixed set of other hieroglyphs. These form the so-called anrasequences, a varying arrangement of the ${ }^{c}$ (D36), $n$ (N35) and $r$ (D21) hieroglyphs, often with additional signs and motifs. The $n$ can be rendered in different ways, but the most common form is the comb, a hori- zontal line divided by short strokes (Richards, 2001: 95), as seen on the cowroid from burial 72510. Their meaning has been the subject of considerable debate among scholars (BenTor, 2007: 133-134; Richards, 2001: 150-160). Anrasequences are first attested on Canaanite scarabs of the Middle Bronze Age $\left(17^{\text {th }}-16^{\text {th }}\right.$ century $\mathrm{BC}$ ), indicating that they are a Levantine concept (Ben-Tor, 2007: 171-175), but they are also imitated, albeit in altered combinations, on archaising Ramesside scarabs. Ramesside anra-sequences show incorrect signs, crudely executed, and are often reduced to alternating $r$ and $n$, or ${ }^{c}$ and $n$ signs (Ben-Tor, in press: figs. 7-10). Anra-like arrangements re-appear in the $9^{\text {th }}$ century $\mathrm{BC}$ on - again, archaising Levantine scarabs (Boschloos, 2016: 49-50; e.g. also Keel, 2013: 98-99 nr. 13, 112-113 nr. 39 ), and few can be ascribed to the Egyptian Third Intermediate Period to Late Period (e.g. Keel, 1997: 34-35 nr. 40). An examination of Fiona Richards' iconographical study of anra-scarabs suggests that the supplementary $h^{c}$ was used on a relatively limited scale (e.g. Richards, 2001: nrs. Ajjul 72, Rishon 4, Megiddo 7, Jericho 16). Such supplementary signs often figure at the top or bottom of the sequence (Richards, 2001: 95-98). Parallels for the cowroid from Cortijo de San Isidro that should be mentioned here are a Ramesside scarab from Tell el-Far'a South (Keel, 2010b: 242-243 nr. 502), and a cowroid from Tell el-Retaba in the Wadi Tumilat (Petrie, 1906: pl. XXIII nr. 42) dating to the Ramesside Period or later.

In conclusion, this cowroid may date as early as the Ramesside period/Late Bronze Age II even though the type continues into the early $1^{\text {st }}$ millennium BC. Since cowroids with anra-like designs are practically unknown from Iron Age II Phoenicia and Third Intermediate Period Egypt, it is possible but unlikely the cowroid is a $1^{\text {st }}$ millennium $\mathrm{BC}$ imitation of a Ramesside model.

\section{Final remarks}

Aegyptiaca such as Egyptian and egyptianising seal-amulets have surfaced in significant numbers in the Iberian Peninsula. The earliest attestations of scarab-shaped seals are found in the south (Andalucía 
and southern Portugal $)^{15}$, from where they are dispersed further inland, for example to Extremadura (Almagro-Gorbea et al., 2009). This contrasts greatly with the distribution pattern in the north-eastern part of the Peninsula (Cataluña and Languedoc-Roussillon) where their presence, attested from the $6^{\text {th }}$ century onwards, seems to be almost exclusively limited to the littoral. More importantly, in the northeast their appearance is linked to the Greeks and thus considered to be the result of the Hellenising processes in the Mediterranean (Almagro-Gorbea and Graells, 2011: 72-73, 81-82), whereas the Phoenicians are considered to have been responsible for the import of these objects in the south part of the Peninsula. If we follow the chronology based on the radiocarbon dates for Cortijo de San Isidro (early $9^{\text {th }}-$ mid $-8^{\text {th }}$ century BC), the date offered for the manufacture of scarab 90124 is quasi contemporary with the context in which it was found (burial 72572/Tomb 1). However, even in spite of the ongoing chronological discussion and following conventional chronology, the finds at Cortijo de San Isidro further substantiate the evidence for the early use of scarabs as apotropaic devices in Phoenician cremation cemeteries in the West. Several of the earliest Phoenician cemeteries on Iberia's Mediterranean coast are located in the region of Málaga (e.g. Cortijo de los Toscanos/Cerro del Mar, Trayamar, Lagos/Las Chorreras and Almuñécar) (Aubet, 2001: 312, 329ff; Padró, 1995: table 3; Pappa, 2013: 70-74, Martín et al. 2014-2015:67-88). Small amulets such as scarabs are present at these sites, albeit in younger or in nonfunerary contexts ${ }^{16}$. For example, a Phoenician scarab from an $8^{\text {th }}$ century BC tomb in Las Chorreras (Martín et al. 2014-2015: fig. 6) dates to the $9^{\text {th }}-8^{\text {th }}$ century BC, based on a parallel from Marsiliana, Italy (Boschloos, 2014b: 15, pl. 9.1) and is therefore deposited in the tomb shortly after it was manufactured, probably in a scarab workshop in the region of Tyre (Boschloos, $2014 b)$. Despite variations in burial types and associated gifts, Phoenician burial customs in Iberia indicate that scarabs are part of the 'typical' burial set, perhaps pointing to shared beliefs regarding the afterlife (Pappa, 2013: 74).

While two of the seal-amulets discussed above had been placed underneath an urn, two were found inside a funerary container. Even though they show traces of burning, they do not seem to have suffered from fire and are in good condition, indicating they had been added to the remnants of the funeral pyre during the funeral and not having been burnt on the pyre with the corpse. The data provided by the CT images and the

15 For general, though outdated overviews, see GamerWallert, 1978: 232-233, abb. 123 and Padró, 1980: 51-52, maps 1-5. A more recent enumeration of scarabs in the Iberian Peninsula is found in Almagro-Gorbea and Torres, 2009: 541 excavation process of the two urns with scarabs inside shows that they were collected and deposited inside the urn together with the cremated bones. Similar circumstances have been reported at the Phoenician cremation necropolis of Tyre al-Bass, which was in use between the (late $10^{\text {th }}$ ) $9^{\text {th }}$ and the mid- $6^{\text {th }}$ century BC. In Tyre, the deceased's personal belongings such as jewellery, beads and amulets (including scarabs), are placed inside the cinerary urns with the cremated remains and ashes, which in turn are accompanied by a set of libation vessels (Aubet, 2014). The ceramic evidence from Cortijo de San Isidro has already been compared with the ceramic repertoire associated with the phases of Tyre al-Bass necropolis and the funeral phases reconstructed and described by Maria Eugenia Aubet offer additional insights in Phoenician funerary practices. It is therefore not surprising to, similarly, find scarabs and other Egyptian(ising) seal-amulets inside the urns at Cortijo de San Isidro. At Tyre, ca. 20 $\%$ of the more than 300 urn burials excavated so far on the al-Bass site (ca. $400 \mathrm{~m}^{2}$ ) contain one or more scarab-shaped seal-amulets. These have been identified as Phoenician and Egyptian, contemporary or dating back as early as the Bronze Age (Boschloos, 2014a). At present, only 12 burials have been excavated at Cortijo de San Isidro, with three of them containing one - or in the case of burial 72510 (Tomb 4) two - Egyptian(ising) seal-amulets. It therefore seems that, as regards the oldest phases of the necropolis, these small items accompanied the deceased in as much as $25 \%$ of burials. With approximatively $87 \mathrm{~m}^{2}$ excavated, however, these numbers cannot (yet) be compared with those from Tyre alBass as they are not representative. This is also the case when looking at other cemeteries in the Phoenician-Punic realm, where the percentages vary considerably but are much more modest for other cemeteries in the Iberian Peninsula when compared with Cortijo de San Isidro ${ }^{17}$. An exception is the necropolis of Hoya de Los Rastros (Ayamonte, Huelva), excavated over an area of $212 \mathrm{~m}^{2}$. Less than a dozen burials have been excavated to date, but most contained a scarab (65\%) (García Teyssandier et al., 2017). However, based on the associated pottery, these burials date to the (late) $8^{\text {th }}$ and $7^{\text {th }}$ centuries $\mathrm{BC}$ and are therefore slightly younger than the burials at Cortijo de San Isidro discussed here. When more burials in the area of La Rebanadilla will have been excavated, the general percentage of burials containing scarab-shaped seals at Cortijo de San Isidro may thus very well alter significantly.

16 Examples in: García and Pérez, 1993-1994; Padró, 1995 : 93-167.

17 For a preliminary assessment, see Almagro-Gorbea and Graells, 2011: 81 
Another final remark pertains to the transfer of function, meaning and symbolism. Unfortunately, few studies that have approached this issue either from the view point of archaeology, art history, or history of religions, have succeeded in providing definite answers on the question to what degree the original meaning of a particular motif, inscription or theme was transferred with objects that travelled this far West. Too many variables are in play, such as i.a. the number of middlemen or places of transit the object passed from its place of origin to its final destination, or whether it was (quasi) contemporary with its period of production or was found in a much younger context. Suggesting that the inscriptions or themes on scarabs can be connected to the function or nature of the archaeological context in which they were discovered is therefore not feasible unless they are in proximity of their place of origin, both geographically and chronologically. Yet, even then, seal-amulets can have multiple functions simultaneously. The fact that the sealamulets discussed above are found in funerary contexts, only indicates that they either belonged to the individual with whom they are buried, or (less likely) to a relative who wished to add this small item of personal adornment during the funeral as a good wish charm. Whether the design on the base was meant to convey a particular message related to the owner (or reference to his/her profession, ethnic background, etc.), is highly debatable. The contexts in which scarabs have surfaced in the Iberian Peninsula suggest that they may have arrived there as objects with a certain (commercial) value: in addition to their ornamental function, having travelled this far West, Egyptian and Phoenician seal-amulets were certainly appreciated for their 'distance value', i.e. becoming 'exotica' that could express one's social status because of the distance from their place of origin. The fact that many of such objects have surfaced in funerary contexts may not only reflect their function as prestigious 'exotica', but also doesn't exclude the possibility that their original apotropaic meaning was transferred ${ }^{18}$.

As for the point of entrance for La Rebanadilla, it is of course from nearby Málaga via the Guadalhorce estuary that the scarabs and other aegyptiaca arrived at their destination further upstream. The coast between Málaga and Almería was indeed much frequented by ships coming from the east, as it is favourably located given the prevailing winds and currents in this part of the Mediterranean, offering safe anchorage before continuing to the Strait of Gibraltar, but also providing access to land routes to Tartessos (Aubet, 2001: 187189, Arancibia et al., 2011: 129-130). About $2 \mathrm{~km}$ downstream is the somewhat younger Phoenician site of Cerro del Villar, which used to be a port on an island in the Guadalhorce's estuary positioned between the Mediterranean and the land route passing through the Guadalhorce valley to Antequera, Sevilla and then Tartessos, thus attesting to the Phoenician interest in this region (Aubet and Delgado 2003; Aubet, 2001, 313-314).

\section{REFERENCES}

Alfaro, C. (2007): "Los entalles mágicos sobre piedras semipreciosas en el mundo antiguo: su técnica de fabricación y su significado" in B. Costa and J. H. Fernández eds. Magia y Superstición en el mundo fenicio-púnico. XXI Jornadas de Arqueología Fenicio-Púnica. Ibiza: 7-47.

Almagro-Gorbea, M., Arroyo, A., Corbí, J. F. M., Marín, B. and Torres, M. (2009): "Los escarabeos de Extremadura: une lectura socioideológica". Zephyrus LXIII: 71-104.

Almagro-Gorbea, M. and Graells, R. (2011): "Escarabeos del noreste de Hispania y del sur de la Galia. Catálogo, nuevos ejemplares e interpretaciones". Lvcentvm XXX : 25-87. https://doi.org/ 10.14198/LVCENTVM2011.30.02

Almagro-Gorbea, M. and Torres, M. (2009): "Los escarabeos fenicios de Portugal. Un estado de la cuestíon". Estudos Arqueológicos de Oeiras 17: 521-554.

Arancibia, A., Galindo, L., Juzgado, M., Dumas, M. and Sánchez V.M. (2011): “Aportaciones de las últimas intervenciones a la arqueología fenicia de la Bahía de Málaga" in M. Álvarez Martí-Aguilar ed. Fenicios en Tartessos: Nuevas perspectivas. BAR International Series 2245. Oxford: 129-149.

Aubet, M. E. $\left(2001,1993^{1}\right)$. The Phoenicians and the West: Politics, Colonies and Trade. Cambridge.

Aubet, M. E. (2014): "Mortuary analysis and burial practices", in M. E. Aubet, F. J. Núñez and L. Trellisó eds. The Phoenician Cemetery of Tyre alBass II. Archaeological Seasons 2002-2005. Bulletin d'Archéologie et d'Architecture Libanaises Hors-série IX. Beirut : 507-529.

Aubet, M. E. and Delgado, A. (2003): "La colonia fenicia del Cerro del Villar y su territorio" in C. Gómez Bellard ed. Ecohistoria del paisaje agrario: La agricultura fenicio-púnica en el Mediterráneo. València : 57-74.

18 On this subject, see i.a. Alfaro, 2007, Almagro-Gorbea, Graells 2011: 80-81, Padró, 1995: 196, and further references cited there. 
Avigad, N. and Sass, B. (1997): Corpus of WestSemitic Stamp Seals. Jerusalem.

Ben-Tor, D. (2007): Scarabs, Chronology and Interconnections. Egypt and Palestine in the Second Intermediate Period. Orbis Biblicus et Orientalis - Series Archaeologica 27. Fribourg/Göttingen.

Ben-Tor, D. (2017): "Ramesside scarabs simulating Middle Bronze Age Canaanite prototypes: Canaanite or Egyptian?". Levante 27: 195-215.

Bisi, A. M. (1992): "Smiting god" in E. Lipiński ed. Dictionnaire de la civilization phénicienne et punique. Turnhout : 419-420.

Boardman, J. (2003): Classical Phoenician Scarabs. A Catalogue and Study. British Archaeological Reports- International Series 1190. Oxford.

Boschloos, V. (2014a): "Scarabs and Seals from the 2002 and 2004 Seasons at Tyre al-Bass" in M. E. Aubet, F. J. Núñez and L. Trellisó eds. The Phoenician Cemetery of Tyre-Al Bass II. Archaeological Seasons 2002-2005. Volume 1. Bulletin d'Archéologie et d'Architecture Libanaises Hors-Série IX. Beirut: 381-404.

Boschloos, V. (2014b.): "Tyre, Achziv and Kition. Evidence for a Phoenician Iron Age II Scarab Seal Workshop" in A. Lohwasser Hrsg. Skarabäen des 1. Jahrtausends. Ein Workshop in Münster am 17. Oktober 2012. Orbis Biblicus et Orientalis 269. Freiburg/Göttingen: 5-36.

Boschloos, V. (2016): "Phoenician Identity through Retro Glyptic. Egyptian Pseudo-inscriptions and the Neo-'Hyksos' Style on Iron Age II - III Phoenician and Hebrew Seals" in G. Garbati and T. Pedrazzi eds. Transformation and Crisis in the Mediterranean II. "Identity" and Interculturality in the Levant and Phoenician West between the $8^{\text {th }}$ and $5^{\text {th }}$ Centuries BCE. Supplemento alla Rivista di Studi Fenici. Roma: 43-59.

Boschloos, V. (2018): "Sardinia, Etruria, Cyprus and the Phoenician Homeland: Reflections on Distribution, Chronology, Typology and Iconography of Scarabs from a "Tyrian Group" in M. Guirgues ed. Dal Mediterraneo all'Atlantico: uomini, merci e idee tra Oriente e Occidente. Proceedings of the $8^{\text {th }}$ International Congress of Phoenician and Punic Studies, CarboniaSant'Antioco, 21 $1^{\text {st }}-26^{\text {th }}$ October 2013. Folia Phoenicia 2. Pisa/Roma.

Buchanan, B. and Moorey, P. R. S. (1988): Catalogue of ancient Near Eastern Seals in the Ashmolean Museum. Volume III. The Iron Age Stamp Seals (c. 1200-350 B.C.). Oxford.

Clerc, G., Karageorghis, V., Lagarce, E. and Leclant, J. (1976): Fouilles de Kition II: Objets égyptiens et égyptisants. Nicosia.
Collon, D. (2005, 1987): First Impressions. Cylinder Seals in the Ancient Near East. London.

Cornelius, I. (1994): The Iconography of the Canaanite Gods Reshef and $\mathrm{Ba}^{\mathrm{c}} \mathrm{al}$. Orbis Biblicus et Orientalis 140. Fribourg/Göttingen.

Cornelius, I. (2004): The Many Faces of the Goddess: The Iconography of the Syro-Palestinian Goddesses Anat, Astarte, Qedeshet, and Asherah c. 1500-1000 BCE. Orbis Biblicus et Orientalis 204. Fribourg/Göttingen.

Cowie, P. J. (2004): "Scarabs" in E. Mazar ed. The Phoenician Family Tomb N.1 at the Northern Cemetery of Akhziv (10 $10^{\text {th }}-6^{\text {th }}$ centuries BCE). Cuadernos de Arqueologia Mediterranea 10. Barcelona: 177-225.

Crowfoot, J. W. and Crowfoot G. M. (1938): SamariaSebaste 2. Early Ivories from Samaria. London.

Dunand, M. (1954): Fouilles de Byblos, 1933-1938. Tome II, 1 Texte. Paris.

Gamer-Wallert, I. (1978): Ägyptische und ägyptisierende Funde von der Iberischen Halbinseln. Beihefte zum Tübinger Atlas des Vorderen Orients. Reihe B (Geiteswissenschaften) 21. Wiesbaden.

García, M. and Pérez, L. (1993-1994): “Avance al estudio de la glíptica en el Museo de Málaga". Mainake XV-XVI: 283-303.

García Teyssandier, E., Marzoli, D., Cabaco, B., Heußner, B. and Gamer-Wallert, I. (2017): "El descubrimiento de la necrópolis fenicia de Ayamonte, Huelva (siglos VIII-VII a.C.)" in J. Jiménez Ávila ed. Sidereum Ana III. El río Guadiana y Tartessos. Mérida: 493-530.

Gardiner, A. (1957, 19271): Egyptian Grammar. Oxford.

Golani, A. (2014): "Cowrie Shells and Their Imitations as Ornamental Amulets in Egypt and the Near East" in A. Golani and Z. Wygnańska eds. Beyond Ornamentation. Jewelry as an Aspect of Material Cuture in the Ancient Near East. Polish Archaeology in the Mediterranean XXIII/2. Warsaw: 71-83.

Griffith, F. L. (1923): “Oxford Excavations in Nubia. XVIII. The Cemetery of Sanam". Liverpool Annals of Archaeology and Anthropology 10: 73-171.

Gubel, E. (1993): "The Iconography of Inscribed Phoenician Glyptic" in B. Sass and C. Uehlinger eds. Studies in the Iconography of Northwest Semitic Inscribed Seals. Proceedings of a Symposium held in Fribourg on April 17-20, 1991. Orbis Biblicus et Orientalis 125. Fribourg/Göttingen: 101-129. 
Gubel, E. (2001): "The Breath of Life or: The Riddle of the Ram-headed Sceptre". Archaeology and History in Lebanon 13: 35-44.

Gubel, E. (2012): “Decoding Phoenician art (I): Pharaoh triumphant”. Rivista di Studi Fenici XL: 21-38.

Hayes, W.C. (1959): The Scepter of Egypt II. A background for the study of the Egyptian antiquities in the Metropolitan Museum of Art. The Hyksos period and the New Kingdom. New York.

Herrmann, G. (1986): Ivories from Nimrud IV (19491963). Ivories from room $S W 37$ Fort Shalmaneser. Commentary and Catalogue (2vols.). London.

Hölbl, G. (1979): Beziehungen der Ägyptischen Kultur zu Altitalien (2 vols.). Études préliminaires aux religions orientales dans l'Empire Romain 62. Leiden.

Hölbl, G. (1986): Ägyptisches Kulturgut im phönikischen und punischen Sardinien (2 vols.). Études préliminaires aux religions orientales dans l'Empire Romain 102. Leiden.

Hornung, E. and Staehelin, E. (1976) : Skarabäen und andere Siegelamulette aus Basler Sammlungen. Mainz.

Jean-Marie, M.-L. (1999) : Mission archéologique de Mari. Tôme V. Tombes et nécropolis de Mari. Bibliothèque Archéologique et Historique de I'IFPO CLIII. Beyrouth.

Jaeger, B. (1982) : Essai de classification et datation des scarabées Menkhéperrê. Orbis Biblicus et Orientalis - Series Archaeologica 2. Fribourg/Göttingen.

Keel, O. (1995): Corpus der Stempelsiegel-Amulette aus Palästina-Israel. Von den Anfang bis zur Perserzeit I Einleitung. Orbis Biblicus et Orientalis - Series Archaeologica 10. Freiburg/Göttingen.

Keel, O. (1997): Corpus der Stempelsiegel-Amulette aus Palästina/Israel. Von den Anfängen bis zur Perserzeit. Katalog. Band 1. Orbis Biblicus et Orientalis - Series Archaeologica 13. Freiburg/Göttingen.

Keel, O. (2010a): Corpus der Stempelsiegel-Amulette aus Palästina/Israel. Von den Anfängen bis zur Perserzeit. Katalog Band II: Von Bahan bis Tel Eton. Orbis Biblicus et Orientalis - Series Archaeologica 29. Freiburg/Göttingen.

Keel, O. (2010b): Corpus der Stempelsiegel-Amulette aus Palästina/Israel. Von den Anfängen bis zur Perserzeit. Katalog Band III: Von Tell el Far'a Nord bis Tell el-Fir. Orbis Biblicus et Orientalis Series Archaeologica 31. Fribourg/Göttingen.

Keel, O. (2013): Corpus der Stempelsiegel-Amulette aus Palästina/Israel. Von den Anfängen bis zur Perserzeit. Katalog. Band IV: Von Tel Gamma bis Chirbet Husche. Orbis Biblicus et Orientalis Series Archaeologica 33. Freiburg/Göttingen.
Keel, O. and Uehlinger, C. (1992): Göttinnen, Götter und Gottessymbole. Neue Erkenntnisse zur Religionsgeschichte Kanaans und Israels aufgrund bislang unerschlossener ikonographischer Quellen. Freiburg.

Mallowan, M. and Herrmann, G. (1974): Ivories from Nimrud III (1949-1963). Furniture from SW.7 Fort Shalmaneser. London.

Markoe, G. (1985): Phoenician Bronze and Silver Bowls from Cyprus and the Mediterranean. Classical Studies 26. Berkeley.

Martín, E., García, D., Vila, M., Peña, V . and Oliver, A. (2014-2015): "Sarcófago fenicio del siglo VIII A.C. en Las Chorreras (Vélez-Málaga. Málaga)”. Mainake XXXV: 67-88.

Navarro, M.J., Sánchez, V.M. and Galindo, L. (2016) : "La Fase I de la necrópolis fenicia arcaica del Cortijo de San Isidro (Bahía de Málaga). Reflejos en Occidente del ritual fenicio de enterramiento a finales del s. IX a.C. ". CUPAUAM 42 : 103-118. https://doi.org/10.15366/cupauam2016.42.003

Nunn, A. (2000): Der figurliche Motivschatz Phöniziens, Syriens und Transjordaniens vom 6. bis zum 4. Jahrhundert v. Chr. Orbis Biblicus et Orientalis - Series Archaeologica 18. Freiburg/Göttingen.

Padró, J. (1980): Egyptian-type documents from the Mediterranean littoral of the Iberian Peninsula before the Roman conquest. I. Introductory survey. Leiden.

Padró, J. (1995): New Egyptian-type Documents from the Mediterranean Littoral of the Iberia, Peninsula Before the Roman Conquest. Orientalia Monspeliensia VIII. Paris/Barcelona.

Pappa, E. (2013): Early Iron Age Exchange in the West: Phoenicians in the Mediterranean and the Atlantic. Ancient Near Eastern Studies Supplement 43. Leuven.

Petrie, W. M. F. (1886): Naukratis. Part I., 1884-5. Memoirs of the Egypt Exploration Fund 3. London.

Petrie, W. M. F. (1888): Tanis. Part II. Nebesheh and Defenneh. Memoirs of the Egypt Exploration Fund 4. London.

Petrie, W. M. F. (1896): Koptos. London.

Petrie, W. M. F. (1906): Hyksos and Israelite Cities. British School of Archaeology in Egypt/Egyptian Research Account 12. London.

Quibell, J. E. (1898): The Ramesseum. The Tomb of Ptah-hotep. British School of Archaeology in Egypt/Egyptian Research Account 2. London.

Régen, I. and Soukiassian G. (2008): Gebel el-Zeit II. Le matériel inscrit. Moyen Empire-Nouvel Empire. IFAO Fouilles 57. Le Caire. 
Rehm, E. (2004): Dynastensarkophage mit scenischen Reliefs aus Byblos und Zypern. Teil 1.1: Der Ahiram-Sarkophag. Maiz-am-Rhein.

Richards, F. (2001): The Anra Scarab. An Archaeological and Historical Approach. British Archaeological Reports. International Series 919. Oxford.

Sánchez, V.M., Galindo, L., Juzgado, M. and Dumas, M. (2011): "La desembocadura del Guadalhorce en los siglos IX y VIII a.C. y su relación con el Mediterráneo" in J. C. Domínguez Pérez ed. Gadir y el Círculo del Estrecho revisados. Propuestas de la arqueología desde un enfoque social. Cádiz 185-200.

Sánchez, V. M., Galindo, L., Juzgado, M. and Dumas, M. (2012): "El asentamiento fenicio de La Rebanadilla a finales del siglo IX a. C. " in E. García Alfonso ed. Diez años de arqueología fenicia en la privincia de Málaga (2001-2010). Sevilla : 67-85.

Sánchez, V.M., Galindo, L., Juzgado, M. \& Belmonte, J.A. (in press): 'La Rebanadilla, otro santuario litoral en el sur de la Península Ibérica" in M. Botto ed. De Huelva a Malaka. Los fenicios en Andalucía a la luz de los descubrimientos más recientes. Collezione di Studi Fenici. Roma.

Schroer, S. (2011): Die Ikonographie Palästinas/Israels und der Alte Orient (IPIAO). Band 3: Die Spätbronzezeit. Fribourg.

Stoof, M. (2002): Skorpion und Skorpiongöttin im alten Ägypten. Antiquitates-Archäologische Forschungergebnisse 23. Hamburg.

Stoof, M. (2015): Kauroide und kauroidähnliche Siegelamulette im alten Ägypten. Hamburg.

Swann Hall, E. (1986): The Pharaoh Smites his Enemies. A Comparative Study. Münchner Ägyptologische Studien 44. München/Berlin.

Teissier, B. (1996): Egyptian Iconography on SyroPalestinian Cylinder Seals of the Middle Bronze Age. Orbis Biblicus et Orientalis - Series Archaeologica 11. Fribourg/Göttingen.
Tufnell, O., Martin, G. T. and Ward, W. A. (1984): Studies on Scarab Seals. Volume Two. Scarab Seals and Their Contribution to History in the Early Second Millennium B. C. (2 vols.). Warminster.

Vercoutter, J. (1945) : Les objets égyptiens et égyptisants du mobilier funéraire carthaginois. Paris.

Von Beckerath, J. (1999, 1984¹ $)$. Handbuch der ägyptischen Königsnamen. Münchner Ägyptologische Studien 49. Mainz.

Von Pilgrim, C. (1996): Elephantine XVIII. Untersuchungen in der Stadt des Mittleren Reiches und der Zweiten Zwischenzeit. Archäologische Veröffentlichungen des deutschen archäologischen Instituts, Kairo 91. Mainz.

Ward, W. A. (1970): “A Phoenician Scarab with a Rare Design: A Winged Isis and Mummiform Osiris". Oriens Antiquus 9: 343-354.

Wicke, D., Busch, A. and Fischer, E. (2010): "Die Goldschale der Iabâ - einde levantinische Antiquität". Zeitschrift für Assyriologie 100 109-141. https://doi.org/10.1515/za.2010.006

Wiese, A. (1993): Die Anfänge der ägyptischen Stempelsiegel-Amulette: eine typologische und religionsgeschichtliche Untersuchung $\mathrm{zu}$ den "Knopfsiegeln" und verwandten Objekten der 6. bis frühen 12. Dynastie. Orbis Biblicus et Orientalis 12. Fribourg/Göttingen.

Winter, I. J. (1981): "Is there a South Syrian style of ivory carving in the early first millennium BC?". Iraq 43(2): 101-130. https://doi.org/10.2307/4200140

Zernecke, A. E. (2008): "Warum sitzt der Skorpion unter dem Bett? Überlegungen zur Deutung eines altorientalischen Fruchtbarkeitssymbols". Zeitschrift des Deutschen Palästina-Vereins 124: 107-127. 